\title{
Perivascular Epithelioid Cell
}

National Cancer Institute

\section{Source}

National Cancer Institute. Perivascular Epithelioid Cell. NCI Thesaurus. Code C45634.

A perivascular cell with abundant clear or eosinophilic cytoplasm that contains glycogen. -

$-2005$ 